Journal of Teaching and Learning with Technology, Vol. 4, No. 2, December 2015, pp.41-50.

\title{
Using Film Clips in the Classroom: Something Old, Something New?
}

\begin{abstract}
Brian R. Levey ${ }^{1}$
Abstract: This essay describes the process by which a new college professor embraced using film clips in an undergraduate Business Law course, with the goal of enhancing student engagement and learning. In particular this paper focuses on: (1) theme days, in which a movie, TV show or actor is used as a vehicle to teach an entire class; and (2) review sessions, in which a film clip is used as a way to review material previously taught, e.g., in anticipation of a test.
\end{abstract}

Keywords: student engagement; student learning; teaching methodology; film, movie, video and TV clips; theme days; review sessions.

In Business Law, we cover everything from free speech to first degree murder -- exciting stuff! Unfortunately, other parts of the course are, frankly, pretty dry. And so as a new professor I went in search of ways to improve the classroom experience for students. Among the things I did to make the course more interesting was to integrate film clips into the classroom in a variety of traditional ways, as well as two somewhat novel approaches: (1) theme days; and (2) review sessions. Students have responded well, indicating that the use of film clips is engaging, in turn leading to what I hope is greater learning and retention.

\section{Background: Film Clips -- Something Old}

As a lawyer turned college professor, I eagerly spent the summer of 2007 preparing to teach four sections of Business Law, a sophomore-level class in the college of business. At some point over the course of the summer though, it occurred to me that the average business major might not share my enthusiasm for all of the topics on the syllabus. An entire chapter devoted to the Statute of Frauds, under which certain types of contracts must be in writing to be enforceable? Boring! Another chapter on the assignment of contractual rights and the delegation of contractual duties? Zzzzzz . . . . What to do? I read the usual how-to manuals (McKeachie \& Svinicki, 2006). I thought back to the classes I had enjoyed over the years, to exercises that my favorite teachers and professors had used. I sought the advice of most everyone I encountered that summer: "who was your favorite teacher, why, what did they do?” Most importantly, I listened to my wife, herself a business professional turned educator.

In general, I was reminded of what I suppose I already knew: teaching begins with enthusiasm and requires stimulating student interest (Filene, 2005). I also discovered that active learning is better than passive, and that multiple channels of communication are better than one (McKeachie \& Svinicki, 2006). As learners, we want our senses stimulated, the more the better, with vision trumping the others (Medina, 2006). What really sticks with students, and the rest of us for that matter? Concrete, emotional stories (Heath \& Heath. 2007). What emerged were a

\footnotetext{
${ }^{1}$ Teaching Professor, Mendoza College of Business, University of Notre Dame, Notre Dame, IN 46556
} 
variety of teaching tools that I hoped would contribute to engagement, comprehension, and ultimately retention -- everything from skits to mock game shows. I also decided to use film clips, both to illustrate legal issues and offer an opportunity for students to apply the law.

I recognize that I was hardly the first college professor to use films clips in the classroom (Berk, 2009). A simple Internet search reveals the use of film clips across disciplines as diverse as architectural history (Handa, 2010), foreign language (Kaiser, 2011), mathematics (Knill, 2012), physics (Chasteen, 2012), and psychology (Green, 2011). Of course, teaching law through the movies is especially fertile ground; entire books focus on law and the movies (Asimov \& Bergman, 1996). A fairly standard approach is to develop a point, show the clip illustrating the point, followed by a review of the point (Rosenberg, 2012). Variations include questioning students before and/or after the clip, e.g., using the clip as a hypothetical and asking them to apply the law. Sometimes students work alone towards an answer; sometimes they work with others (e.g., think, pair, share.)

A few challenges emerged, some technical, some generational. At least initially, the easiest way to show the clip was to use the in-class VCR (remember those?), and more recently the DVD player or disc drive in the computer. Of course, I had to cue the clip before class, start it, stop it, rewind it for the next class, and so on. A slicker method proved to be copying the clip from the video or DVD and embedding it in a PowerPoint presentation. ${ }^{2}$ Even better, over time more and more clips became available on the Internet, making clips one click away after embedding the link in the PowerPoint presentation. In addition to YouTube, dedicated sites like MOVIECLIPS.com emerged.

Over time, I built up a library of clips. Sadly, clips from my favorite movies like Judgment at Nuremberg and Twelve Angry Men required a lot of explanation as only one or two students per class had seen the films. Of course, when I asked how many students had seen Billy Madison or Borat, almost every hand went up. Centuries from now historians will trace the fall of Western Civilization to the rise in popularity of Adam Sandler and Sacha Baron Cohen.

\section{A Different Approach: Film Clips -- Something New?}

As the semesters passed, I developed two somewhat distinctive uses of clips in the classroom: (1) theme days; and (2) review sessions.

\section{Theme Days}

As noted earlier, one of the less gripping chapters in the Business Law text covers the Statute of Frauds. How does one engage the typical undergraduate student with respect to the legal requirement for certain contracts to be in writing to be enforceable? The answer came in the form of Jerry Maguire, the seemingly ubiquitous Tom Cruise movie on cable TV. Early in the film, sports agent Jerry Maguire (Cruise) scrambles to retain his clients after being fired from his firm. He cements one relationship with Frank Cushman (Beau Bridges), the father of the presumptive number one pick in the upcoming NFL draft. Sealing their deal with a handshake, Cushman

\footnotetext{
${ }^{2}$ In this effort, I had the assistance of others more technically sophisticated than I. And so a 'how to' guide is beyond the scope of this article. Also beyond the scope of this article is a discussion of the copyright issues associated with showing and copying clips.

Journal of Teaching and Learning with Technology, Vol. 4, No. 2, December 2015. jotlt.indiana.edu
} 
states emphatically: "You know I don't do contracts, but what you do have is my word. And it's stronger than oak." Questions abound. Is this a contract? What are its terms? Does it fall under the Statute of Frauds? Does the father have authority to bind the son?

If a series of questions about this scene were good, wouldn't more legal questions drawn from Jerry Maguire, Tom Cruise's other movies, and his personal life be better? Before too long "Tom Cruise Day" emerged and a fifty minute class on the Statute of Frauds became at least a little bit more interesting courtesy of the three-time Academy Award nominee and tabloid sensation. As it stands today, the questions range from substantive to silly, e.g., late in the class, when eyelids are growing heavy and attention short, I ask students to vote on their favorite Tom Cruise movie. ${ }^{3}$ Top Gun seems to be the perennial favorite, in case you are wondering.

In this same vein, over time I have developed various other theme days for use throughout the semester. As students walk into the classroom, a PowerPoint presentation scrolls, much like they would see in a movie theater before the trailers for coming attractions appear. The presentation features trivia questions, fun facts, and related information about that day's theme. The slide show is accompanied by music, often drawn from the soundtrack of that day's featured film, or other films in which that day's actor has starred. In addition to establishing the theme, this has the added benefits of creating positive energy, focusing students' attention, and making it easier to start class at the appointed time. Class typically begins with a clip from a movie (or TV show) and then I intersperse related questions throughout the class, to break up what is mostly lecture (regrettably, due to class size). Examples include:

- Denzel Washington Day - I show a clip from Philadelphia to illustrate employment discrimination. In the film, Andrew Beckett (Tom Hanks) has been dismissed from his position with a law firm because he has AIDS. He tries to persuade fellow attorney Joe Miller (Washington) to take his wrongful-termination case, asking him to read from relevant precedent, which Miller does: "This is the essence of discrimination: Forming opinions about others not based on their individual merits but rather their membership in a group with assumed characteristics." Throughout the class, I then intersperse questions drawn from the scene, the movie, the characters, and the actors.

- Kevin Costner Day - I show a clip from Field of Dreams to illustrate the requirement for contractual consideration. Under the law, each party to a contract typically must get something of value for the contract to be binding. In the movie, Iowa farmer Ray Kinsella (Costner) has plowed under acres of corn to build a baseball field, in response to mysterious voices. Growing frustrated, he says to the ghost of Shoeless Joe Jackson (Ray Liotta), one of the long-deceased major leaguers who have come to play on Ray's field: "I did it all. I listened to the voices, I did what they told me, and not once did I ask what's in it for me." Consideration is sort of like this; each party needs to ask "what's in it for me?” Again, questions drawn from the scene, the movie, the characters, and the actors follow.

3 We use a student-response system called Poll Everywhere to vote (Levey, 2011).

Journal of Teaching and Learning with Technology, Vol. 4, No. 2, December 2015. jotlt.indiana.edu 
The list goes on:

- Breaking Bad Day, drawing from the story of a chemistry teacher turned drug lord to explain criminal law;

- George Costanza Day, featuring the Seinfeld character and world's worst employee to illustrate employment law;

- Entourage Day, using the fictional Hollywood super-agent Ari Gold from this HBO series, and now feature film, to showcase agency relationships;

- Iron Man Day, examining the remedies associated with Stark Industries' contractual breaches; and

- Kim Kardashian Day, using the multimedia star and her extended family to illustrate emerging legal concepts relating to the Internet, social media and privacy.

No, there probably will never be a movie made about the Statute of Frauds, contractual consideration, or many of the other mundane topics we cover in Business Law, but through the use of film clips and theme days these topics come to life.

\section{Review Sessions}

Another technique that I developed over time was the use of film clips to review material that we previously had covered. For example, in my first semester of teaching I asked the students to play "Name that Tort" after we had finished the assigned chapters on intentional torts and negligence. I showed the opening sequence from Raiders of the Lost Ark to the class. The scene involves Indiana Jones (Harrison Ford) entering a cave to remove a golden idol belonging to the Hovitos tribe. I broke the students into teams and provided them with a fill-in-the-blank sheet, i.e., a long narrative drawn from the scene, with blanks for the appropriate legal terms. For example:

When Indiana Jones enters the cave without the permission of the Hovitos, he commits the tort of idol, he commits the tort of [trespass to property] When he removes the golden . [conversion]

I gave them the rest of the class period to complete the exercise. Students were surprised at how many torts were committed in the first few minutes of the film, so many that no team won by completing the sheet within the allotted time. Subsequent semesters featured similar exercises with scenes from:

- Flubber, to review the intellectual property rights arising out of flying rubber;

- It Could Happen to You, to review contract issues resulting from a promise to share lottery winnings in lieu of a tip; and

- Heaven Can Wait, using legal issues facing a board of directors, as a final, cumulative review for the semester.

\section{Results}

Journal of Teaching and Learning with Technology, Vol. 4, No. 2, December 2015. jotlt.indiana.edu 
The results have been positive. Over the years, I have consistently received encouraging comments from students. Some are short: "I love the themes," "MORE MOVIE CLIPS!," "Awesome." Still other students are more to the point:

[Using film clips] helped me so much during the exams! I recalled certain situations that happened in the films we watched during class and it helped me remember rules/exceptions/etc. I actually wrote down what happened in the videos on my notes, so when I was studying everything felt easier.

The above student agrees with faculty who have used film clips in the classroom and shared their observations:

[M]edia complements many traditional approaches to learning. The method is engaging, aids student retention, motivates interest in the subject matter, and helps illustrate the relevance of many concepts. Utilizing media increases the efficiency of the learning process and helps to transfer knowledge by actively engaging the audience or learner. For example, effective instructors attempt to support positive transfer of information by building bridges between students' knowledge and the learning objectives of the course.

As a consequence, the use of media serves as a scaffold to help transfer knowledge from the instructor to the student (Mateer \& Stepehenson, 2011).

At the close of the fall 2012 semester, I added two questions to the university's "Course Information Feedback" system (Appendix 1). Of the 150 students who participated, 144 or ninety six percent (96\%) responded "Strongly Agree" to the statement "Using films clips makes this class more engaging." Similarly, almost ninety nine percent (98.66\%) strongly agreed or somewhat agreed with the statement "Using films clips in this class helps me learn," with the great majority (74.83\%) strongly agreeing. Similar results emerged in the fall of 2013 (Appendix 2). While these questions measure student opinion and do not definitively demonstrate actual engagement and learning, the results are certainly positive and supportive. ${ }^{4}$ By using film clips in the classroom, especially in the review context, I ask students to apply skills and knowledge across diverse contexts; the hope is that this facilitates their ability to apply what they have learned, both today in the classroom and at a later time elsewhere in life, arguably the central goal of education (Ambrose et al., 2010).

Perhaps the best feedback I received was when a student whistled the theme from Raiders of the Lost Ark on the way out of class -- that was a good day. Other highlights include the occasional email from a current or former student suggesting that I use a movie they just saw to illustrate a topic we covered in class, allowing me to think that the use of movie clips resonates with students, often long after the course has ended.

\section{Recommendations}

\footnotetext{
${ }^{4}$ By comparison, I did not test two groups of students using the same set of questions, one group without having used the relevant film clip, another group with, to see if there is any measurable and attributable difference.
}

Journal of Teaching and Learning with Technology, Vol. 4, No. 2, December 2015. jotlt.indiana.edu 
As noted above, I am hardly the first professor to use films clips in the classroom. And so it is not a stretch to say that the use of film clips in connection with theme days and review sessions should not be limited to a Business Law course. One could easily envision a day devoted to Wall Street, and its tabloid stars Michael Douglas and Charlie Sheen, to explore a number of concepts in a Business Ethics course, or the use of a clip from the film to review those concepts previously taught. Likewise, The Devil Wears Prada is fertile ground for a Management course, in particular a class or review session on leadership. Meryl Streep Day anyone? Although perhaps college-age students might affiliate more with co-star and fellow Academy Award winner Anne Hathaway. In any event, the possibilities are endless.

As for me, having built up a library of clips, questions, and review exercises, the greatest challenge at this point is keeping the clips current. This presents something of a dilemma. On the one hand, I am constantly on the lookout for relevant scenes to illustrate legal issues as I watch movies, TV shows, etc. (it has become something of an addiction), but my viewing habits skew 'old,' demographically speaking. I also have something of a bias toward expanding the students' horizons and exposing them to movies they probably have not seen. On the other hand, my sense is that the impact of the clip is heightened if it is from a movie students have seen, and so I make an effort to view content I might otherwise happily forgo. Sadly for my wife, this included watching Borat a few years back; she lasted about ten minutes into the film. "But it's for the kids,” I said, as she left the room and I forged ahead. And so the search continues.

Journal of Teaching and Learning with Technology, Vol. 4, No. 2, December 2015. jotlt.indiana.edu 
Appendix 1: Student Feedback Fall 2012

\begin{tabular}{|l|c|c|c|c|c|}
\hline Questions & $\begin{array}{c}\text { Strongly } \\
\text { Agree }\end{array}$ & $\begin{array}{c}\text { Somewhat } \\
\text { Agree }\end{array}$ & $\begin{array}{c}\text { Not Sure / } \\
\text { No Opinion }\end{array}$ & $\begin{array}{c}\text { Somewhat } \\
\text { Disagree }\end{array}$ & $\begin{array}{c}\text { Strongly } \\
\text { Disagree }\end{array}$ \\
\hline $\begin{array}{l}\text { Using film clips } \\
\text { makes the class } \\
\text { more engaging }\end{array}$ & $\begin{array}{c}144 / 150 \\
(96 \%)\end{array}$ & $\begin{array}{c}5 / 150 \\
(3.33 \%)\end{array}$ & 0 & $1 / 150$ & 0 \\
& $\begin{array}{c}(.67 \%) \\
\text { Using film clips in } \\
\text { class helps me learn }\end{array}$ & $\begin{array}{c}110 / 149 \\
(73.8 \%)\end{array}$ & $\begin{array}{c}37 / 149 \\
(24.8 \%)\end{array}$ & 0 & $2 / 149$ \\
$(1.4 \%)$ & 0 \\
\hline
\end{tabular}

Appendix 2: Student Feedback Fall 2013

\begin{tabular}{|l|c|c|c|c|c|}
\hline Questions & $\begin{array}{c}\text { Strongly } \\
\text { Agree }\end{array}$ & $\begin{array}{c}\text { Somewhat } \\
\text { Agree }\end{array}$ & $\begin{array}{c}\text { Not Sure / } \\
\text { No Opinion }\end{array}$ & $\begin{array}{c}\text { Somewhat } \\
\text { Disagree }\end{array}$ & $\begin{array}{c}\text { Strongly } \\
\text { Disagree }\end{array}$ \\
\hline $\begin{array}{l}\text { Using film clips } \\
\text { makes the class } \\
\text { more engaging }\end{array}$ & $\begin{array}{c}132 / 144 \\
(91.67 \%)\end{array}$ & $\begin{array}{c}11 / 144 \\
(7.64 \%)\end{array}$ & 0 & $\begin{array}{c}1 / 144 \\
(.69 \%)\end{array}$ & 0 \\
\hline $\begin{array}{l}\text { Using film clips in } \\
\text { class helps me learn }\end{array}$ & $\begin{array}{c}113 / 141 \\
(80.2 \%)\end{array}$ & $\begin{array}{c}22 / 141 \\
(15.6 \%)\end{array}$ & $\begin{array}{c}2 / 141 \\
(1.4 \%)\end{array}$ & $\begin{array}{c}(1.4 \%) \\
(1.4 \%)\end{array}$ \\
\hline
\end{tabular}

Journal of Teaching and Learning with Technology, Vol. 4, No. 2, December 2015. jotlt.indiana.edu 


\section{References}

Ambrose, S. A., Bridges, M. W., Dipietro, M., Lovett, M. C. and Norman, M. K. (2010). How learning works: 7 research-based principles for smart teaching (pp. 108, 111-112, 117-118). San Francisco, CA: John Wiley \& Sons.

Beatty, W. (Director). (1978). Heaven can wait [Motion picture on DVD]. United States: Paramount Pictures.

Bergman, A. (Director). (1994). It could happen to you [Motion picture on DVD]. TriStar Pictures.

Bergman, P. and Asimow, M. (1996). Reel justice: the courtroom goes to the movies. Kansas City, MO: Andrews and McMeel.

Berk, R. A. (2009). Multimedia teaching with video clips: TV, movies, YouTube, and mtvU in the college classroom. International Journal of Teaching and Learning, 5(1), 1-21.

Charles, L. (Director). (2007). Borat: cultural learnings of America for make benefit glorious nation of Kazakhstan [Motion picture on DVD]. United States: Twentieth Century Fox Film Corporation.

Chasteen, S. (2012, May). The magic of the silver screen: movie clips to inspire curiosity in the classroom [Web log post]. Retrieved from http://theactiveclass.com/2012/05/11/the-magic-ofthe-silver-screen-movie-clips-to-inspire-curiosity-in-the-classroom

Crowe, C. (Director). (1996). Jerry Maguire [Motion picture]. United States: TriStar Pictures.

David, L. (Writer). (1989-1998). Seinfeld [Television series]. NBC.

Davis, T. (Director). (1995.) Billy Madison [Motion picture on DVD]. United States: Universal Studios.

Demme, J. (Director). (1993). Philadelphia [Motion picture on DVD]. United States: TriStar Pictures.

Ellin, D. (Writer). (2004-2011). Entourage [Television series]. HBO.

Favreau, J. (Director). (2008). Iron Man [Motion picture on DVD]. United States: Paramount Pictures.

Filene, P (2005). The joy of teaching: a practical guide for new college instructors, 7 . Chapel Hill, NC: The University of North Carolina Press.

Frankel, D. (Director). (2006). The devil wears Prada [Motion picture on DVD]. United States: Twentieth Century Fox Film Corporation.

Journal of Teaching and Learning with Technology, Vol. 4, No. 2, December 2015. 
Gilligan, V. (Writer). (2008-2013). Breaking bad [Television series]. AMC.

Green, R. J. (2011, March 7). Teaching psychology through film, video [Web log post].

Retrieved from http://www.psychologicalscience.org/index.php/uncategorized/teachingpsychology-through-film-video.html

Handa, R. (2010). Using popular film in the architectural history classroom. Journal of Architectural Historians, 69(3), 311-319. Retrieved from

http://digitalcommons.unl.edu/cgi/viewcontent.cgi?article=1013\&context=arch_facultyschol

Heath, C \& Heath, D (2007). Made to stick: why some ideas thrive and others die (pp.17-18). New York, NY: Random House.

Kaiser, M. (2011). New approaches to exploiting film in the foreign language classroom. $L 2$ Journal, 3, 232-249. Retrieved from http://escholarship.org/uc/item/6568p4f4

Knill, O. (2013, March). Mathematics in movies. Retrieved from http://www.math.harvard.edu/ knill/mathmovies/

Kramer, S. (Director). (1961). Judgment at Nuremberg [Motion picture on DVD]. United States: United Artists.

Levey, B. R. (2011). In-class polling: less teaching, more learning? In Teaching with technology: the stories continue (Vol. 2). Retrieved from http://ltcessays.files.wordpress.com/2011/03/01levey.pdf.

Lumet, S. (Director). (1957). Twelve angry men [Motion picture on DVD]. United States: MGM Studios.

Mateer, G. D. and Stephenson, E. F. (n.d.). Using film clips to teach public choice economics. Journal of Economics, 10(1). Retrieved Summer, 2011, from http://cafehayek.com/wpcontent/uploads/2011/07/Dirk-Mateer-and-Frank-Stephenson-explain-how-to-use-film-clips-tobetter-convey-to-students-the-lessons-of-public-choice-economics..pdf

Mayfield, L. (Director). (1997). Flubber [Motion picture on DVD]. United States: Walt Disney Pictures.

McKeachie, W.J. \& Svinicki, M (2006). Teaching tips: strategies, research, and theory for college and university teachers (pp. 242-243, 233-234). Boston, MA: Houghton Mifflin Company.

Medina, J (2008). Brain rules: 12 ideas for surviving and thriving at work, home, and school (pp. 71, 197, 221). Seattle, WA: Pear Press.

Journal of Teaching and Learning with Technology, Vol. 4, No. 2, December 2015. jotlt.indiana.edu 
Robinson, P. A. (Director). (1989). Field of dreams [Motion picture on DVD]. United States: Universal Pictures.

Rosenberg, S. (n.d.). Classroom use of movie clips or banishing boredom: how Hollywood can help [Web log post]. Retrieved May 25, 2012, from at

http://www.law.suffolk.edu/faculty/addinfo/golann/VideoTeaching/videoRoom.cfm (n.d.)

Scott, T. (Director). (1986). Top gun [Motion picture]. United States: Paramount Pictures.

Spielberg, S. (Director). (1981). Indiana Jones and the raiders of the lost ark [Motion picture on DVD]. United States: Paramount Pictures.

Stone, O. (Director). (1987). Wall Street [Motion picture on DVD]. United States: Twentieth Century Fox Film Corporation.

Journal of Teaching and Learning with Technology, Vol. 4, No. 2, December 2015. 